\title{
MANAJEMEN PROYEKSI SISTEM INFORMASI
}

\section{NI WAYAN DAMAYANTI}

175100013

Universitas Mitra Indonesi, Sistem Informasi

Niwayandamayanti.student@umitra.ac.id

\begin{abstract}
Abstrak
Manajemen merupakan sebuah proses terpadu dimana individu-individu sebagai bagian dari organisasi yang dilibatkan untuk merencanakan, mengorganisasikan, menjalankan dan mengendalikan aktifitas-aktifitas, yang kesemuanya diarahkan pada sasaran yang telah ditetapkan dan berlangsung terus menerus seiring dengan berjalannya waktu. Agar proses manajemen berjalan lancar, diperlukan sistem serta struktur organisasi yang solid. Pada organisasi tersebut, seluruh aktifitasnya haruslah berorientasi pada pencapaian sasaran.Organisasi tersebut berfungsi sebagai wadah untuk menuangkan konsep, ide-ide manajemen. Jadi dapat dikatakan bahwa manajemen merupakan suatu rangkaian tanggung jawab yang berhubungan erat satu sama lainnya.
\end{abstract}

Kata kunci : Manajemen, Sistem informasi, Manajemen Proyek 
Universitas Mitra Indonesia

Ni wayan

damayanti 


\section{A. PENDAHULUAN}

Manajemen atau pengelolaan proyek (selanjutnya ditulis manajemen proyek saja) adalah suatu disiplin ilmu pada era tahun 1950-an, Amerika bangsa yang pertama kali menggunakan ilmu manajemen proyek. Henry Gantt dapat dikatakan bapak dari ilmu manajemen proyek, dan namanya pun menjadi metode yang digunakan, bernama "Gantt Chart". Perlu diingat bahwa mempelajari Manajemen Proyek itu tidak terlalu sulit, karena didalamnya terdapat hal-hal yang terbiasa dilakukan oleh manusia, hanya ditambahkan sedikit logika dan aturan yang khusus. Sedangkan Proyek itu usaha yang harus dilakukan dari awal hingga akhir pada suatu kejadian,yang mempunyai batasan waktu - anggaran - sumber daya yang dibutuhi oleh pelanggan. Meskipada akhir tujuan dari adanya proyek adalah untuk memuaskan pelanggan.

Maksudnya begini, ketika ada suatu perusahaan besar maupun kecil me-manajemen terpenting adalah waktu yang tepat dalam membuat dan memustuskan prediksi, serta penggunaan sumber daya dan laporan dalam penyampaian produk atas hasil dari proyek yang dijalankan.

Lalu bagaimana kita mengetahui bahwa itu adalah "proyek"? Diperlukan beberapa ciri-ciri atau karakteristik dari proyek, yaitu: ada sasaran atau tujuan, memiliki rentang waktu atau deadline, waktu biaya dan syarat kerja yang lengkap, berurutan dari a hingga z, terkadang merupakan sesuatu event atau kejadian yang sebelumnya belum pernah dilakukan.

\section{B. TINJAUAN PUSTAKA}

Manajemen atau pengelolaan proyek (selanjutnya ditulis manajemen proyek saja) adalah suatu disiplin ilmu pada era tahun 1950-an, Amerika bangsa yang pertama kali menggunakan ilmu manajemen proyek. Henry Gantt dapat dikatakan bapak dari ilmu manajemen proyek, dan namanya pun menjadi metode yang digunakan, bernama "Gantt Chart". 


\section{STUDY KASUS}

\subsection{Pengertian Manajemen, Proyek dan Manajemen Proyek}

\subsubsection{Pengertian Manajemen}

Manajemen merupakan sebuah proses terpadu dimana individuindividu sebagai bagian dari organisasi yang dilibatkan untuk merencanakan, mengorganisasikan, menjalankan dan mengendalikan aktifitas-aktifitas, yang kesemuanya diarahkan pada sasaran yang telah ditetapkan dan berlangsung terus menerus seiring dengan berjalannya waktu. Agar proses manajemen berjalan lancar, diperlukan sistem serta struktur organisasi yang solid. Pada organisasi tersebut, seluruh aktifitasnya haruslah berorientasi pada pencapaian sasaran.Organisasi tersebut berfungsi sebagai wadah untuk menuangkan konsep, ide-ide manajemen. Jadi dapat dikatakan bahwa manajemen merupakan suatu rangkaian tanggung jawab yang berhubungan erat satu sama lainnya.

Skill apa sih yang harus di butuhkan bagi seorang Manajer Proyek? Skill yang dibutuhkan ada 4 titik, yaitu kepada Owner, User, Lingkungan, dan Team. Maksudnya, ketika seorang manajer proyek berurusan dengan owner (komisaris perusahaan) dapat memberikan informasi berupa biaya atau budget dari segi finansial, serta resiko kedepan yang akan dihadapi. Ketika berbicara dengan user, dapat mengajak untuk menggunakan hasil dari proyek, baik melobi dan bujuk rayu. Lalu ketika berbicara dengan team tentunya harus memiliki keahlian tehnis, dapat mengarahkan, dan tentunya manajerial skill harus dimiliki. Terakhir ketika berbicara dengan lingkungan dalam hal ini pemerintah atau masyarakat sekitar, dapat meminta persetujuan atau izin akan adanya pengadaan proyek tersebut.

Manajer proyek adalah seseorang yang memiliki tanggung jawab terbesar atas pelaksanaan proyek. Pekerjaan utama dari manajer proyek adalah mengarahkan, mengawasi dan mengendalikan proyek dari awal sampai selesai. Halhal yang perlu dilakukan seorang manajer proyek adalah: 
1. Manajer proyek harus mendefinisikan proyek, merinci proyek menjadi serangkaian tugas yang mudah dikelola, memperoleh sumber daya yang dibutuhkan, dan membentuk tim kerja untuk melaksanakan tugas-tugas tersebut.

2. Manajer proyek harus menetapkan tujuan akhir dari proyek dan memotivasi anggota timkerja untuk menyelesaikan proyek tepat waktu.

3. Manajer proyek harus menginformasikan kepada stakeholder tentang perkembangan pelaksanaan proyek secara periodik.

4. Manajer proyek harus mengenali resiko yang mungkin terjadi dan meminimalkan dampak terhadap penyelesaian proyek.

5. Manajer proyek harus beradaptasi terhadap perubahan-perubahan, karena tidak ada proyek yang $100 \%$ berjalan sesuai dengan yang direncanakan.

Berkaitan dengan tugas-tugas seorang manajer, maka area kemampuan yang perlu dimiliki oleh

Manajer proyek yang baik tidak menghindari semua resiko, tetapi 
menyiapkan proses dan prosedur standar untuk berusaha mencegah resiko yang mungkin terjadi seperti:

a. Keterlambatan penyelesaian proyek, pembengkakkan anggaran atau keingingan konsumen tidak terpenuhi.

b. Tidak konsisten antara proses dan prosedur yang digunakan manajer proyek.

c. Proyek tidak bermanfaat dan membuang-buang waktu dan biaya.

d. Tidak sinerginya faktor internal dan eksternal yang mempengaruhi proyek.

\subsubsection{Pengertian Proyek}

Proyek merupakan suatu tugas yang perlu dirumuskan untuk mencapai sasaran yang dinyatakan secara kongkrit serta harus diselesaikan dalam suatu periode tertentu dengan menggunakan tenaga manusia dan alat-alat yang terbatas dan begitu kompleks sehingga dibutuhkan pengelolaan dan kerjasama yang berbeda dari yang biasanya digunakan.

Menurut DI Cleland dan Wr. King
(1987), proyek merupakan gabungan dari berbagai sumber daya yang dihimpun dalam organisasi sementara untuk mencapai suatu tujuan tertentu. Selain itu proyek juga: Bertujuan menghasilkan produk atau kerja akhir tertentu. Dalam proses mewujudkan produk tersebut di atas, ditentukan jumlah biaya, jadwal, serta kriteria mutu. Bersifat sementara, dalam arti umurnya dibatasi oleh selesainya tugas. Titik awal dan titik akhir ditentukan dengan jelas. Nonrutin, tidak berulang-ulang. Macam dan intensitas kegiatan berubah sepanjang berlangsungnya proyek. Timbulnya suatu proyek antara lain dilatar belakangi oleh:

a. Rencana pemerintah. Misalnya proyek pembangunan jalan.

b. Permintaan pasar. Misalnya terjadi kenaikan permintaan suatu produk dalam jumlah besar,maka perlu dibangun sarana produksi baru.

c. Dari dalam perusahaan yang bersangkutan. Misalnya suatu perusahaan akan memperbarui (modernisasi) perangkat, sistem 
kerja, atau sistem informasi yang lama agar lebih mampu bersaing.

d. Dari kegiatan penelitian dan pengembangan. Dari kegiatan penelitian dan pengembangan diperkirakan dapat dihasilkan produk baru yang banyak manfaat dan peminatnya, sehingga dibangun fasilitas produksinya.

- Macam-Macam Proyek:

Menurut R.D Achibalt (1976), macam-macam proyek adalah sebagai berikut:

a. Proyek Kapital (Modal). Meliputi: pembebasan tanah, pembelian material dan peralatan, desain mesin, dan kostruksi guna pembangunan instalasi pabrik baru.

b. Proyek pengembangan produk baru adalah kegiatan untuk menciptakan produk baru yang biasanya merupakan gabungan antara proyek kapital dan proyek riset dan pengembangan. Contoh : penemuan alat elektronik karaoke.

c. Proyek penelitian dan pengembangan berupa kegiatan untuk melakukan penelitian dengan sasaran yang ditentukan. d. Proyek sistem informasi adalah kegiatan yang sifatnya spesifik dengan mempergunakan alatalat pemrosesan data (data processing personal dan alatalat lainnya).

e. Proyek yang berkaitan dengan manajemen: perusahaan merancang reorganisasi, perusahaan merancang program efisiensi, dan penghematan merancang diversifikasi.

\subsubsection{Manajemen Proyek}

Manajemen proyek merupakan suatu usaha merencanakan, mengorganisasi, mengarahkan, mengkoordinasi, dan mengawasi kegiatan dalam proyek sedemikian rupa sehingga sesuai dengan jadwal waktu dan anggaran yang telah ditetapkan. Suatu pekerjaan rutin biasanya berlangsung secara kontinu, berulang-ulang dan berorientasi ke proses. Sebagai suatu proses yangterus menerus, pekerjaan yang 
rutin tidak dianggap suatu proyek.

Manajemen proyek adalah suatu cara mengelola, mengarahkan, dan mengkoordinasikan sumber daya (manusia/material) disaat mulainya sebuah proyek hingga akhir untuk mencapai suatu tujuan, yang dibatasi oleh biaya, waktu, dan kualitas untuk mencapai kepuasan.

Pengelola dalam sebuah proyek disebut sebagai Manajer Proyek. Manajer proyek bertanggung jawab untuk mengatur dan mengawasi semua kegiatan pelaksanaan proyek, agar sesuai dengan standar kualitas, biaya dan waktu. Dan tentunya selalu bertanggungjawab untuk selalu berkomunikasi dengan tim, atasan (owner), dan pelanggan (user). Maksudnya manajer harus mampu memberikan contoh tehnik, mampu mengambil keputusan yang tepat, dan pemimpin yang dapat memberikan informasi berupa laporan kepada atasan.

- Manfaat manajemen proyek:

a) Mengidentifikasi fungsi tanggung jawab

b) Meminimalkan tuntutan pelaporan rutin

c) Mengidentifikasi batas waktu untuk penjadwalan

d) Mengidentifikasi metode analisa peramalan

e) Mengukur prestasi terhadap rencana

f) Mengidentifikasi masalah dini \& tindakan perbaikan

g) Meningkatkan kemampuan estimasi untuk rencana

h) Mengetahui jika sasaran tidak dapat dicapai/terlampaui

Contoh manajemen proyek diantaranya adalah: membangun sebuah stadion sepak bola, megelola penelitian berskala besar, melaksanakan pembedahan transplantasi organ tubuh, memasang lintas produksi, atau berjuang mendapatkan ijazah strata satu di suatu perguruan tinggi. Konsep Manajemen Proyek: Manajemen proyek sistem informasi ditekankan pada tiga faktor, yaitu : manusia, masalah dan proses. Dalam pekerjaan sistem informasi factor manusia sangat berperan penting dalam suksesnya 
manajemen proyek. Pentingnya faktor manusia dinyatakan dalam model kematangan kemampuan manajement manusia (a people management capability maturity model atau PM-CMM) yang berfungsi untuk meningkatkan kesiapan organisasi perangkat lunak (sistem informasi) dalam menyelesaikan masalah dengan melakukan kegiatan menerima, memilih, kinerja manajemen, pelatihan, kompensasi, pengembangan karier, organisasi dan rancangan kerja serta pengembangan tim.

\section{Dasar-Dasar Organisasional :}

Organisasi adalah sistem yang saling mempengaruhi dan saling bekerja sama antara orang yang satu dengan orang yang lain dalam suatu kelompok untuk mencapai suatu tujuan tertentu yang telah disepakati bersama. Organisasi merupakan sistem maka terdiri dari beberapa elemen yaitu:

a) orang, dalam organisasi harus ada sekelompok orang yang bekerja dan salah satunya ada yang memimpin organisasi tersebut.

b) tujuan, dalam organisasi harus ada tujuan yang harus dicapai, baik dalam jangka pendek maupun jangka panjang.

c) posisi, setiap orang yang ada dalam suatu organisasi akan menempati posisi atau kedudukannya masing-masing.

d) pekerjaan, setiap orang yang ada dalam organisasi tersebut mempunyai pekerjaan (job) masing-masing sesuai dengan posisinya.

e) teknologi, untuk mencapai tujuan organisasi membutuhkan teknologi untuk membantu dalam pengolahan data menjadi suatu informasi.

f) struktur, struktur organisasi merupakan pola yang mengatur pelaksanaan pekerjaan dan hubungan kerja sama antar setiap orang yang ada dalam organisasi tersebut.

g) lingkungan luar, merupakan elemen yang sangat penting dan akan mempengaruhi keberhasilan 


\begin{abstract}
suatu organisasi, misalnya adanya kebijakan pemerintah tentang organisasi.
\end{abstract}

Prinsip-prinsip organisasi adalah nilai-nilai yang digunakan sebagai landasan kerja bagi setiap orang yang ada dalam organisasi tersebut untuk mencapai keberhasilan tujuan yang telah disepakati. Prinsip-prinsip yang ada dalam organisasi meliputi :

a) Tujuan organisasi yang jelas

b) Tugas yang dilakukan harus jelas

c) Pembagian tugas yang adil

d) Penempatan posisi yang tepat

e) Adanya koordinasi dan integrasi

\subsection{Kebijakan dan Perencanaan Proyek Sistem Informasi}

Sistem Informasi memiliki pengertian suatu sistem yang memiliki fungsi menghasilkan informasi-informasi yang dibutuhkan pihak user. Komponen yang termasuk sistem informasi meliputi infrastruktur hardware, Software dan ketersediaan sumber daya manusia bidang teknologi informasi. Proyek sistem informasi mencakup sebagian atau keseluruhan dari rangkaian aktivitas rekayasa pembangunan sistem informasi.

Contoh-contoh proyek sistem informasi:

a) Proyek sistem informasi untuk mendukung pelaksanaan pemilu.

b) Proyek pembangunan infrastruktur E-Government di Jawa Tengah.

C) Proyek pengembangan sistem CRM (Customer Relationship Management) pada di PTGaruda.

d) Proyek pembansgunan sistem Ebusiness pada PT. Global Jaya.

e) Proyek penjualan elektronik (ECommerce).

Beberapa perbedaan karakteristik proyek sistem informasi dibandingkan dengan proyek bidang lain adalah sebagai berikut :

a) Memiliki tujuan untuk menghasilkan produk yang bersifat intangible (tidak dapat diperkirakan, tidak dapat dinyatakan secara jelas) seperti perangkat lunak, database, jaringan yang sulit untuk mengukur nilai manfaat dari produk tersebut.

b) Melibatkan teknologi yang 
sangat cepat usang, karena perkembangan yang sangat cepat.

c) Membutuhkan beragam sumber daya manusia dengan keahlian dan kompetensi yang beragam.

d) Ukuran yang dijadikan standar sulit dibakukan, karena sulit mengukur kualitas yang dimengerti berbagai pihak secara seragam.

Suatu sistem informasi dapat dikembangkan karena adanya kebijakan dan perencanaan terlebih dahulu. Tanpa adanya perencanaan sistem yang baik, pengembangan sistem tidak akan dapat berjalan sesuai dengan yang diharapkan. Tanpa adanya kebijakan pengembangan sistem oleh manajemen puncak, maka pengembangan sistem tidak akan mendapat dukungan darimanajemen puncak tersebut.

Kebijakan Sistem Kebijakan untuk mengembangkan sistem informasi dilakukan oleh manajemen puncak karena manajemen menginginkan untuk meraih kesempatankesempatan yang ada yang tidak dapat diraih oleh sistem yang lama atau sistem lama mempunyai kelemahan (masalah) perencanaan sistem menyangkut estimasi (penafsiran, perkiraan, pendapat atau penilaian) sumber daya (kebutuhankebutuhan fisik dan tenaga kerja) dan biaya. Perencanaan sistem terdiri dari : perencanaan jangka pendek (periode 1-2 tahun) dan jangka panjang (periode sampai 5 tahun).

Perencanaan sistem biasanya ditangani oleh staf perencanaan sistem, departemenpengembangan sistem atau depertemen pengolahan data.

Proses Perencanaan Sistem Proses perencanaan sistem dapat dikelompokkan dalam tiga proses utama, yaitu :

1. Merencanakan proyek-proyek sistem

Tahapan proses perencanaan sistem yaitu :

a) Mengkaji tujuan, perencanaan strategi dan taktik perusahaan.

b) Mengidentifikasi proyek-proyek sistem.

c) Menetapkan sasaran proyekproyek sistem.

d) Menetapkan kendala proyek- 
proyek sistem (mis. Batasan biaya, waktu, umurekonomis, peraturan yang berlaku).

e) Menetukan prioritas proyekproyek sistem.

f) Membuat laporan perencanaan sistem.

g) Meminta persetujuan manajemen.

2. Mempersiapkan proyek-proyek sistem yang akan dikembangkan

Persiapan ini meliputi :

a) Menunjuk team analis dapat berasal dari departemen pengembangan yang ada atau dari luar perusahaan (konsultan).

b) Mengumumkan proyek pengembangan sistem.

3. Mendefinisikan proyek-proyek sistem yang dikembangkan

Melakukan studi untuk mencari alternative pemecahan terbaik yang paling layak untuk dikembangkan. Tahapan yang dilakukan yaitu :

a) Mengidentifikasi kembali ruang lingkup dan sasaran proyek system.

b) Melakukan studi kelayakan.

c) Menilai kelayakan proyek system. d) Membuat usulan proyek system.

e) Meminta persetujuan manajemen.

Perkiraan Proyek Sistem Informasi Sekarang biaya merupakan elemen yang paling penting dan mahal dalam pengembangan sistem berbasis komputer. Perkiraan biaya yang salah atau kurang tepat dapat mengurangi keuntungan atau malah kerugian. Perkiraan biaya sistem informasi dan usaha tidak dapat dihitungdengan tepat, karena banyak variabel (manusia, teknikal, lingkungan) yang mempengaruhinya. Untuk mencapai perkiraan biaya dan usah yang dapat diandalkan, digunakan pilihan sebagai berikut :

$\checkmark$ Memperkirakan waktu yang paling lama dari pengerjaan proyek.

$\checkmark$ Perkiraan berdasarkan pada proyek yang sama.

$\checkmark$ Menggunakan teknik dekomposis.

$\checkmark$ Menggunakan satu atau lebih model empiris.

Memperkirakan waktu untuk menyelesaikan setiap kegiatan 
merupakan bagian yang paling sulit, untuk itu butuh pengalaman dalam memperkirakan waktu yang diperlukan. Penjadwalan tugas-tugas (kegiatan) dapat menggunakan :

\section{Grafik Gantt}

Merupakan suatu grafik dimana ditampilkan kotak-kotak yang mewakili setiap tugas (kegiatan) dan panjang masing-masing setiap kotak menunjukkan panjang relatif tugas-tugas yang dikerjakan.

2. Diagram PERT (Program Evaluation and Review Techniques)

Suatu program (proyek) diwakili dengan jaringan simpul dan tanda panah yang kemudian dievaluasi untuk menentukan kegiatan-kegiatan terpenting, meningkatkan jadwal yang diperlukan dan merevisi kemajuan-kemajuan saat proyek telah dijalankan.

Diagram PERT lebih baik dari Gantt, karena :

a. Mudah mengidentifikasi tingkat prioritas.

b. Mudah mengidentifikasi jalur kritis dan kegiatan-kegiatan kritis.

c. Mudah menentukan waktu kendur. d. Penjadwalan proyek berbasis komputer.

Menggunakan PC untuk membuat jadwal proyek lebih praktis dan menguntungkan. Contohprogram penjadwalan yaitu Ms Project, Symantec's Timeline dan Computer Associates' CA-Super Project. Proses pengembangan sistem informasi dikembangkan oleh pelaku-pelaku yang dapat dikatagorikan dalam 5 kelompok :

a) Manajer senior, yang bertugas mendefinisikan permasalahanpermasalahan bisnis dan sangat berpengaruh pada proyek tersebut.

b) Manajer proyek (teknik), yang merencanakan, memotivasi, mengorganisasi dan mengontrol orang-orang yang bekerja dalam proyek tersebut (praktisi).

c) Praktisi, adalah orang yang mempunyai kemampuan teknis yang dibutuhkan untukmendapatkan produk sistem informasi (program aplikasi).

d) Pelanggan, adalah orang yang membutuhkan sistem informasi 
$(\mathrm{PL})$ tersebut.

e) Pengguna akhir, orang yang berinteraksi dengan sistem informasi (PL) yang dikaitkan dengan penggunaan produk.

Sedangkan contoh Manajemen Proyek antara lain:

1. Proyek pembuatan Robot

2. Proyek Pembuatan Website

3. Proyek Pembuatan Software

4. Proyek Pembuatan Aplikasi

\subsection{Metodologi Umum Pleaksanaan Proyek Sistem Informasi (Metodologi Generik)}

Pengembangan sebuah sistem informasi dalam sebuah perusahaan dilakukan dengan pendekatan manajemen proyek (project management). Lepas dari berbagai variasi proyek-proyek teknologi informasi yang ada seperti pembuatan aplikasi, penerapan perangkat lunak, konstruksi infrastruktur jaringan, dan lain sebagainya - metodologi yang dipergunakan secara umum adalah sama. Setidak-tidaknya ada enam buah tahapan yang harus dilalui : perencanaan, analisa, desain, konstruksi, implementasi, dan pasca implementasi. Masing-masing konsultan atau para praktisi teknologi informasi biasanya memiliki variasinya masing-masing yang secara prinsip tidak lepas dari keenam langkah metodologi di atas.

Secara umum, proyek-proyek sistem informasi dalam perusahaan atau organisasi dapat dikategorikan dalam 3 kelompok besar.

a) Proyek yang bersifat pembangunan jaringan infrastruktur teknologi informasi, menyangkut hal-hal mulai dari pengadaan dan instalasi computer sampai dengan perencanaan danpengembangan infrastruktur jaringan LAN (Local Area Network) dan WAN (Wide AreaNetwork).

b) Implementasi dari paket program aplikasi yang dibeli di pasaran dan diterapkan diperusahaan, mulai dari software kecil seperti produkproduk retail Microsoft sampai dengan aplikasi terintegrasi berbasis ERP, seperti SAP dan BAAN.

c) Perencanaan dan pengembangan 
aplikasi yang dibuat sendiri secara khusus (customizedsoftware), baik oleh internal perusahaan maupun kerja sama dengan pihak luar seperti konsultan dan software house.

Lepas dari perbedaan tersebut, secara garis besar ada 6 tahap yang bisa dijadikan sebagai batu pijakan atau metodologi dalam melaksanakan aktivitas pengembangan tersebut.

\subsubsection{Tahap Perencanaan}

Tahap perencanaan merupakan suatu rangkaian kegiatan semenjak ide pertama yang melatarbelakangi pelaksanaan proyek ini didapat, pendefinisian awal terhadap kebutuhan detail atau target yang harus dicapai dari proyek tersebut, penyusunan proposal, penentuan metodologi dan sistem manajemen proyek yang digunakan, sampai dengan penunjukan tim dan instruksiuntuk mengeksekusi (memulai) proyek yang bersangkutan. Biasanya ada dua pihak yang terlibat langsung dalam proyek perencanaan ini yaitu : a) Pihak yang membutuhkan (demand side) eksistensi dari suatu sistem informasi, dalam hal ini adalah perusahaan, lembaga, institusi atau organisasi yang bersangkutan.

b) Pihak yang berusaha menjawab kebutuhan tersebut (supply side) dalam bentuk pengembangan teknologi informasi. Kelompok ini biasanya merupakan gabungan dari parapersonel yang terkait dengan latar belakang ilmu dan pengetahuan yang beragam (multi disiplin), seperti ahli perangkat lunak, analisis bisnis dan manajemen, spesialis perangkat keras, programmer, sistem analis, praktisi hukum, manajer proyek dan beberapa karakteristik SDM lain yang terkait.

Dilihat dari segi manajemen proyek sistem informasi, output yang harus dihasilkan tahap perencanaan adalah berupa jadwal detail dari kelima tahapan berikutnya menyangkut masalah waktu, target yang dapat disampaikan (deliverable), personel yang 
bertanggung jawab, aspek-aspek keuangan dan hal-hal lain yang berkaitan dengan pendayagunaan sumber daya yang dipergunakan dalam proyek. Sebagai tambahan, standar-standar dan prosedur yang akan dipergunakan dalam melakukan pengelolaan proyek pun harus jelas dan disepakati bersama oleh seluruh anggota personel.

\subsubsection{Tahap Analisis}

Secara prinsip ada 2 aspek yang jadi fokus analisis, yaitu :

1. Aspek bisnis atau manajemen

Analisis aspek bisnis dimulai dengan mempelajari karakteristik perusahaan yang bersangkutan, mulai dari aspek-aspek historis, struktur kepemilikan, visi, misi, kunci keberhasilan usaha (critical success factors), ukuran kinerja (performance measurements), strategi, programprogram dan hal terkait lainnya.

Tujuan dilakukannya langkah ini :

a) Mengetahui posisi atau peranan teknologi informasi yang paling sesuai dan relevan diperusahaan (mengingat setiap perusahaan memiliki pandangan tersendiri dan unik terhadap sumber daya teknologi yang dimiliki, yang membedakannya dengan perusahaan lain).

b) Mempelajari fungsi-fungsi manajemen dan aspek-aspek bisnis terkait yang akan berpengaruh (memiliki dampak tertentu) terhadap proses desain, konstruksi dan implementasi.

\section{Aspek teknologi}

Analisis aspek teknologi meliputi kegiatan-kegiatan yang bersifat menginventarisir aset teknologi informasi yang dimiliki perusahaan pada saat proyek dimulai dengan berbagai tujuan,antara lain :

a) Mempelajari infrastruktur teknologi informasi yang dimiliki perusahaan dan tingkat efektivitas penggunaannya selama kurun waktu tersebut.

b) Menganalisis kemungkinankemungkinan diperlukannya penambahan sistem di kemudianhari (system upgrading) sehubungan akan diimplementasikannya teknologi baru.

Keluaran dari proses analisis di 
kedua aspek ini adalah isu-isu (permasalahan) penting yang harus segera ditangani, dianalisis penyebabnya, dampaknya bagi bisnis perusahaan, beberapa kemungkinan scenario pemecahan dengan segala resiko cost atau benefit (laba atau rugi) dan trade-off (tukar tambah), serta pilihan solusi yang direkomendasikan. Sebelum memasuki fase desain, seluruh tim harus paham tentang isu-isu ini dan memiliki komitmen untuk melanjutkan proyek

yang ada ke tahap berikutnya sesuai dengan skala prioritas yang telah ditentukan (setelah memilih scenario yang disetujui bersama).

\subsubsection{Tahap Desain}

Pada tahap desain, tim teknologi informasi bekerja sama dengan tim bisnis atau manajemen melakukan perancangan komponenkomponen sistem terkait. Tim teknologi informasi akanmelakukan perancangan teknis dari teknologi informasi yang akan dibangun, seperti sistem basis data, jaringan computer, metode interfacing, teknik konversi data, metode migrasi sitem dansebagainya.

Model-model umum seperti Flowchart, ER Diagram, DFD dan lain sebagainya dipergunakan sebagai notasi umum dalam perancangan sistem secara teknis. Sementara itu secara paralel dan bersama-sama tim bisnis atau manajemen akan melakukan perancangan terhadap komponen-komponen organisasi yang terkait seperti prosedur (SOP = Standar OperationProcedures), struktur organisasi, kebijakankebijakan, teknik pelatihan, pendekatan SDM dan sebagainya. Tim ini pun biasanya akan mempergunakan model-model umum seperti Porter'sValue Chain, Bussiness Process Mapping, Strategic Distinction Model, BCG Matrix, dan lain-lain. Jelas bahwa hasil tahap ini, yang berupa cetak biru rancangan sistem, secara teknis dan secara manajemen akan dijadikan pegangan dalam proses konstruksi dan implementasi komponenkomponen pada sistem informasi yang akan dikembangkan. 


\subsubsection{Tahap Konstruksi}

Berdasarkan desain yang telah dibuat, konstruksi atau pengembangan sistem yang sesungguhnya (secara fisik) dibangun. Tim teknis merupakan tulang punggung pelaksana tahap ini, mengingat semua hal yang bersifat konseptual harus diwujudkan dalam suatu konstruksi teknologi informasi dalam skala detail. Dari semua tahapan yang ada, tahap konstruksi inilah yang biasanya paling banyak melibatkan sumber daya terbesar, terutama dalam hal SDM, biaya, waktu. Control terhadap manajemen proyek pada tahap konstruksi harus diperketat agar tidak terjadi ketidak efisienan maupun ketida kefektifan dalam penggunaan beragam sumber daya yang ada (yang secara tidaklangsung akan berdampak langsung terhadap keberhasilan proyek sistem informasi yang diselesaikan secara tepat waktu).

Akhir dari tahap konstruksi biasanya berupa uji coba sistem. Perbaikan-perbaikan bersifat minor biasanya harus dilakukan setelah adanya masukan-masukan yang timbul setelah diadakannya evaluasi.

\subsubsection{Tahap Implementasi}

Tahap Implementasi merupakan tahap yang paling kritis karena untuk pertama kalinya sistem informasi akan dipergunakan di dalam perusahaan. Biasanya, pendekatan yang dipergunakan oleh perusahaan adalah pendekatan cut off dan paralel.

a) Pendekatan cut off atau bigbang adalah suatu strategi implementasi yang memilih sebuah hari sebagai patokan dan terhitung mulai hari tersebut, sistem baru mulai dipergunakan dan sistem lama ditinggalkan sama sekali.

b) Pendekatan paralel dilakukan dengan cara melakukan pengenalan sistem baru sementara sistem lama belum ditinggalkan, sehingga dua buah sistem berjalan secara paralel (kedua sistem tersebut biasa disebut testing environment dan production environment).

Pemilihan terhadap kedua 
strategi tersebut tergantung pada perusahaan masing-masing, karena masing-masing strategi implementasi memiliki keuntungan dan kerugian yang berbeda. Lepas dari strategi yang dipilih, pemberian pelatihan (training) harus diberikan kepada semua pihak yang terlibat sebelum tahap implementasi dimulai. Selain untuk mengurangi resiko kegagalan, pemberian pelatihan juga berguna untuk menanamkan rasa memiliki terhadap sistem baru yang diterapkan, sehingga seluruh jajaran pengguna atau SDM dengan mudah menerima sistem tersebut dan memeliharanya dengan baik di masa-masa mendatang. Evaluasi secara berkala perlu dilakukan untuk menilai kinerja sistem baru yang diterapkan dan untuk mengetahui isu-isu permasalahan yang timbul. Tentu saja pemecahan masalah dalam tahap implementasi harus segera dicari agar penggunaan sistem tersebut efektif.

Proyek sistem informasi biasanya ditutup setelah tahap implementasi dilakukan. Namun ada satu tahapan lagi yang harus dijaga manajemennya, yaitu tahap pasca implementasi.

\subsubsection{Tahap Pasca-implementasi}

Dari segi teknis, yang dimaksud dengan aktivitas-aktivitas pasca implementasi adalah bagaimana manajemen pemeliharaan sistem akan dikelola (maintenance, supports and services management). Seperti halnya sumber daya yang lain, sistem informasi akan mengalami perkembangan dikemudian hari.

Hal-hal seperti modifikasi sistem, interfacing ke sistem lain,perubahan hak akses sistem, penanganan terhadap fasilitas pada sistem yang rusak, merupakanbeberapa contoh dari kasus-kasus yang biasa timbul dalam pemeliharaan sistem. Di sinilah perlunya dokumentasi yang baik dan transfer of knowledge dari pihak pembuat sistem ke SDM perusahaan untuk menjamin terkelolanya prosesproses pemeliharaan sistem. Tidak jarang terjadiperistiwa dimana perusahaan atau personel pembuat 
sistem sudah tidakdiketahui lagi lokasinyasetelah bertahun-tahun (mungkin perusahaannya tutup, atau yang menangani sistem sudah pindahke tempat kerja lain). Bisa dibayangkan bagaimana perusahaan pemakai sistem terpaksa membuang sistemnya (membuat sistem baru lagi) atau melakukan tambal sulam (yang secarateknis sangat berbahaya karena tingkat integritas data yang buruk) akibat tidak adanya dokumentasi teknis yang baik atau infrastruktur manajemen pemeliharaan yang efektif.

Dari segi manajemen, tahap pasca implementasi adalah berupa suatu aktivitas, harus ada personel atau divisi dalam perusahaan yang dapat melakukan perubahan atau modifikasi terhadap sistem informasi sejalan dengan perubahan kebutuhan bisnis yang teramat dinamis. Dengan kata lain, dalam era kompetisi sekarang, perusahaan harus mampu berubah dengan sangat cepat. Sistem informasi atau teknologi informasi yang secara teknis tidak dapat beradaptasi terhadap perubahan kebutuhan bisnis perusahaan sudah selayaknya tidak mendapatkan tempat yang baik. Apakah teknologi informasi di perusahaan-perusahaan dapat dengan mudah mengikuti perubahan kebutuhan bisnis secara cepat? Jika belum, sudah waktunya bagi pemimpin perusahaan untuk berbicara dengan departemen atau divisi yang bertanggung jawab terhadap teknologi informasi perusahaan Anda. Dan kenyataannya, sudah ada teknologi yang dapat menjawab kebutuhan ini, dan itu sudah terbukti efektif. Tidak ada tempat bagi perusahaan modern pada tahun 2000 yang masih menggunakan pendekatan sistem informasi dan teknologi informasi secara konservatif (bagi sebagian perusahaan besar di Indonesia pendekatan tersebut masih dianggap sebagai pendekatan termodern).

Studi kasus Proyek Pembuatan Software

Proses pembuatan software tidak cukup hanya dikerjakan dalam waktu beberapa hari saja. Ada beberapa tahapan yang harus dilalui 
dalam proses pembuatan software. Setiap tahapan bisa memerlukan waktu cukup lama, bisa satu bulan, dua bulan, atau bahkan satu tahun. Tahapan-tahapan itu yaitu : requirement (perencanaan dan analisa), design (pembuatan), dan testing (pengujian dan pemeliharaan). Setiap tahapan yang dilalui terdapat beberapa permasalahanpermasalahan yang timbul.

Pada permasalahan ini akan dibahas beberapa permasalahan yang timbul dengan studikasus pembuatan software Sistem Informasi Akademik dan juga akan dibahas solusi yang dapat diambil untuk mengatasi beberapa permasalahan tersebut. Pembahasan permasalahan ini dibagi dalam setiap tahapan pembuatan software.

\section{a) Tahap Requirement}

Pada tahap ini, kegiatan yamg paling banyak dilakukan adalah dengan melakukan interaksi dengan user. Permasalahan dalam proses pembuatan software yang dapat timbul pada tahap iniadalah :

1. Permasalahan spesifikasi kebutuhan Kebutuhan akan fitur dan report yang diinginkan seringkali tidak sesuai dengan sistem yang ada. Misalnya pada sistem Informasi Akademik, user menginginkan report pembayaranSPP, sedangkan sistem ini hanya mengenai masalah akademik perkuliahan.

2. Ketidak sepahaman sistem antara developer dan user Seringkali antara developer dan user dikarenakan perbedaan pemahaman, terjadi ketidak sepahaman mengenai alur Sistem Informasi Akademik, misalnya alur mulai dari mahasiswa bayar SPP, daftar ulang, pengisian FRS, proses perkuliahan sampai nilai akhir UAS keluar.

3. Metode analisa sistem

Metode analisa sistem yang digunakan oleh developer tidak sesuai dengan kondisi/ behaviouruser.

\section{b) Tahap Design}

Pada tahap ini, merupakan tahap yang dilakukan oleh developer. Permasalahan dalam proses 
pembuatan software yang dapat timbul pada tahap ini adalah:

1. Metode pembuatan software

Metode dan tools yang digunakan hasilnya tidak optimal, sesuai dengan keinginan user.

2. Organisasi pembuatan software

Tidak adanya koordinasi pada saat proses pembuatan software, sehingga terjadi modul-modul yang tidak dapat digabungkan. Misalnya tidak sesuainya nama tabel, field, atau tipe data yang digunakan.

\section{c) Tahap Testing}

Pada tahap ini, merupakan tahap pengujian software yang dilakukan antara developer dan user, dan diakhiri dengan pemeliharaan software. Permasalahan dalam proses pembuatan software yang dapat timbul pada tahap ini adalah:

1. Perubahan regulasi sistem

Adanya perubahan regulasi sistem, misalnya perubahan evaluasi penilaian dari 5 tingkat penilaian ( $A, B, C, D, E)$ menjadi 7 tingkat penilaian $(A, A B, B, B C, C, D$, E). Hal ini menyebabkan perubahan tabel dan field nya.

2. Ketidak sesuaian keinginan user dengan software yang telah dibuat Pengujian software yang dilakukan antara user dan developer tidak memenuhi keinginan user.

3. Tidak adanya Risk Management Hal ini menyebabkan tidak ada langkah-langkah yang akan dilakukan apabila terjadi revisi atau pun pada masa garansi/ maintenance. Untuk mengatasi beberapa permasalahan tersebut diatas, perlu dilakukan analisa untuk mendapat solusinya. Ada beberapa solusi yang dapat diambil, antara lain :

1. Membuat dokumen kontrak antara developer dan user sebelum proses pembuatan software.

2. Perlu adanya assessment pada saat survey data, wawancara, ataupun analisa data. Assessment ini ditandangani kedua belah pihak, user dan developer.

3. Menggunakan requirement tool untuk proses requirement sehingga dapat dihasilkan requirement yang sesuai dengan kebutuhan user.

4. Menentukan Proces Model yang 
akan digunakan pada awal proses pembuatan software, dapat menggunakan waterfall model, RAD model, spiral model, atau model lainnya.

5. Membuat project management pada proses pembuatan software dengan dikoordinasi seorang penanggung jawab.

6. Menentukan software programming untuk semua modul yang akan dibuat, termasuk tabel, relasi, dan struktur data.

7. Membuat dokumen Berita Acara Pengujian Software sehingga dapat dinilai tingkat kepuasaan user terhadap software yang telah dibuat.

8. Developer melakukan evaluasi total setiap selesai pembuatan software sebelum pengujian.

Solusi yang lain secara teknis adalah membuat software Sistem Informasi Akademik yang dinamis, dimana user dapat melakukan update sistem secara mandiri dan berkala tanpa perlu berhubungan dengan developer kembali. Misalnya, membuat perubahan evaluasi penilaian, evaluasi absensi, aturan penilaian, perubahan kurikulum, dan sebagainya. Tetapi untuk membuat software Sistem Informasi Akademis yang dinamis tersebut memerlukan waktu yang tidak sedikit dan juga membutuhkan biaya yang cukup besar.

Maka hal yang paling penting dilakukan dalam proses pembuatan software Sistem Informasi Akademik adalah komunikasi yang intensif dan efektif antara user dan developer, baik itu pada tahap requirement, design, maupun testing.

Dengan adanya komunikasi yang intensif danefektif tersebut maka dapat diketahui sampai seberapa jauh software dinamis yang dibutuhkanoleh user. Sehingga tingkat kepuasan user dapat terjaga.

\section{DISKUSI}

Manajemen proyeksi? Apa itu ?

A. Manajemen proyeksi merupakan suatu usaha merencanakan, mengorganisasi, mengarahkan, mengkoordinasi, dan mengawasi kegiatan dalam proyek sedemikian rupa sehingga sesuai dengan 
jadwal waktu dan anggaran yang telah ditetapkan.

B. Proyek Sistem Informasi Sekarang biaya merupakan elemen yang paling penting dan mahal dalam pengembangan sistem berbasis komputer.

C. suatu perusahaan besar maupun kecil me-manajemen proyek, yang terpenting adalah waktu yang tepat dalam membuat dan memustuskan prediksi, serta penggunaan sumber daya dan laporan dalam penyampaian produk atas hasil dari proyek yang dijalankan.

\section{E. KESIMPULAN}

1. Manajemen merupakan sebuah proses terpadu dimana individuindividu sebagai bagian dari organisasi yang dilibatkan untuk merencanakan, mengorganisasikan, menjalankan dan mengendalikan aktifitasaktifitas, yang kesemuanya diarahkan pada sasaran yang telah ditetapkan dan berlangsung terus menerus seiring dengan berjalannya waktu.

2. Menurut DI Cleland dan Wr. King (1987), proyek merupakan gabungan dari berbagaisumber daya yang dihimpun dalam organisasi sementara untuk mencapai suatu tujuantertentu.

3. Manajemen proyek adalah suatu cara mengelola, mengarahkan, dan mengkoordinasikan sumber daya (manusia atau material) disaat mulainya sebuah proyek hingga akhir untuk mencapai suatu tujuan, yang dibatasi oleh biaya, waktu, dan kualitas untuk mencapai kepuasan.

4. Lepas dari berbagai variasi proyek-proyek teknologi informasi yang ada seperti pembuatan aplikasi, penerapan perangkat lunak, konstruksi infrastruktur jaringan, dan lain sebagainya-metodologi yang dipergunakan secara umum adalah sama. Setidak-tidaknya ada enam buah tahapan yang

\section{F. REFERENSI}

[1] PUTRA, Arie Setya; FEBRIANI, Ochi 
Marshella, Knowledge Management Online Aplication in PDAM Lampung Province. In: Prosiding International Conference On Information Technology and Business (ICITB).2018.P.181-187.

[2] FEBRIANI, Ochi Marshella; PUTRA,Arie Setya. Sistem Informasi Monitoring Inventori Barang Pada Balai Riset Standardisasi Industri Bandar Lampung. Jurnal Informatika,2014,13:1:90-98

[3] PUTRA,A.S.(2018.July9). 2018 Artikel Struktur Data, Audit dan Jaringan Komputer, Retr1ievedfrom osf.io/3uq8w.

[4] Hariyanto, Bambang. 2000. Struktur Data. Bandung: CV. Informatika. Modul Dasar StrukturData"BSI".
[5] Desphande P.S., O.G. Kakde (2004).C dan Data Structures. Charles River Media, Inc.Massachusetts. 